\title{
521
}

521

$\mathrm{J} 5$

opy 1

\section{QUAKER HILL}

S E R I E S

XII. The JBook Jarmer.

BY

EDWARD H. JENKINS, PH. D. 
The Quaker Hill Conference is held annually, the first week in September, at Quaker Hill, Dutchess County, N. Y. It is a gathering for the promotion of Bible study, for the discussion of vital problems of the present day and for the quickening of the spiritual life. 


\title{
THE BOOK FARMER
}

\section{AN ADDRESS}

BY

\author{
EDWARD H. JENKINS, PH. D.
}

DIRECTOR OF THE CONNECTICUT AGRICULTURAL FXPEFIUENT STATIOK, NEW HAVEN, CONNECTICUT.

READ AT THE FIFTH ANNYAL MEETING OF THE QUAKER HILL CONFERENCE, AUGUST THE FIFTEENTH, NINETEEN HUNDRED AND THREE.

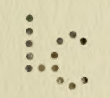

Published ax the Quaker Hill Conferench Association QUaker HiLL, NKW York.

1904 


\section{Publications}

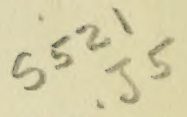

OF the Quaker Hill Conference Association

A Critical Studr of the Bible, by Rev. Newton $\mathbf{M}$. Hall of Springfield, Mass.

The Relation of the Church at Home to the Church Abroad, by Rev. George William Knox, D. D.. of New York.

A Tenable Theory of Biblical Inspiration, by Prof. Irving Francis Wood of Northampton, Mass.

The Book Farmer, by Edward H. Jenkins, Ph, D., of New Haven, Conn.

\section{LOCAL HISTORY SERIES}

David Irish-A Memoir, by his daughter, Mrs. Phœbe T. Wanzer of Quaker Hill, N. Y.

Quaker Hill in the Eighteenth Century, by Rev. Warren H. Wilson of Brooklyn, N. Y.

Quaker Hill in the Nineteenth Century, by Rev. Warren H. Wilson of Brooklyn. N. Y.

Hiram B. Jones and His School, by Rev. Edward L. Chichester of Quaker Hill, N, Y.

Richard Osborn-A Reminiscence, by Margaret B. Monahan of Quaker Hill, N, Y.

Albert $\boldsymbol{J}$. Akin-A Tribute, by Rev. Warren H. Wilson of Brooklyn. N, Y,

Ancient Homes and Early Days at Quaker Hill, by Amanda Akin Stearns of Quaker Hill, N. Y.

Thomas Taberand Ed'waril Shove-A Reminiscence -by Rev. Benjamin Shoveref "Now York.

Any one of these publications may be had by addressing the Secretary, Rev. Edwarn L. Chichester.

Quaker Hill, N. Y.

Price Ten Cents. Twelve Cents Postpaid. 


\section{THE BOOK FARMER.}

I am to speak for a little while this evening on The Book Farmer. The term itself is almost obsolete. It belongs to the medieval period of American Farming, and is ready to perish.

Today every American farmer is, in some sense, a book farmer. He cannot but be one. He may deride the name, he may scorn books, he may refuse or neglect to read them, but for all that and in spite of himself he is, in some sense, to some extent, a book farmer.

In a conference of this kind, it will not, I hope, be out of place to show what I mean in this fashion. We are all, in a certain sense, Christians. We may deny the dogma, we may refuse the name, we may be unchristian in much of our conduct. Yet our law, our social life, our political economy, even our business practice,--evil and immoral as it is in many ways, -is tinc- 
tured with the Christian spirit. The principles of the Sermon on the Mount shine through all our civilization. The Christian attitude of mind towards the problems of life we have inherited from our forefathers; it is in our blood and we cannot, if we will, rid ourselves of it.

Many of us, whose intellectual beliefs may have wandered very far from the formal creeds of the Christian church, yet call ourselves Christians, for we see that while some must struggle after new light and fight what they regard as serious errors of doctrine, and search the foundations of belief, it is for us who are doing the world's common work under a Christian civilization to which we are bound, not to spend much time in kicking against the pricks, but to make of ourselves the very best Christian men and women that we can; to do out the daily duty, which needs all our care, knowing that the abstract truth will come in good time, without our care, like the morning.

Now the farmer lives surrounded by books, and reading and readers. Every day he reads or hears of what was done yesterday in every corner of the earth. Every day new books come from the press, 
discussing every last item of human knowledge, - some of them also, it must be confessed, discussing, in many pages, things about which it is perfectly clear that at present we know nothing,- - and these new books are eagerly read in city and country as a part almost of the daily food.

Moreover, there is more published information, cheaply or gratuitously furnished, regarding the business of farming than regarding any other business, and there is no business which has been so materially stimulated and improved in its methods by this published matter as the business of farming. In my own state, within my memory, dairying, fruit growing, tobacco growing and cattle feeding have been almost revolutionized, largely by aid of scientific research and the publication in popular form and free distribution of the results of such work. It is in the air. It is a matter of common discussion. The practice and the results of book-farming are seen everywhere.

Can a man farming in the midst of all thís by any means protect himself against its influences? Surely not. As well might he stand in the pouring rain and insist that he never allowed himself to get wet. That 
is what I mean by saying that every American farmer is, in some sense, a book farmer.

There are two sorts of them, as there are two sorts of Christians. The one sort came by his book farming or by his kind of Christianity just as the catechism says we all came by that mysterious thing "original sin;" that is, "by ordinary generation," by inheritance, and unconsciously. The other gets his book farming by labor and pains. Now let us be of this second kind, worthy of our time and of our opportunities. That is the text of my farm sermon.

What is farming?

The farmer, and with him I include the grazier, provides the food, and that means the energy, for the world's work. Every piece of work that is done by animals, whether it be drawing a load, digging a trench or writing a poem, is possible only by an expenditure of physical energy. This energy cannot be created by the animal, but is latent in the food which it eats and is merely developed by the animal from its food. Follow back now the food of animals and men and seek the source of its energy, its power for work, and you will find it always and only in field crops which draw it, not from the earth, but from the sun. 
The world does not supply energy to run itself any more than does a steam engine. This energy comes from the sun and is collected and held and stored in crops gathered either by hand or by grazing. Not by the throbbing of any mighty machinery of human building, nor in the confused bustle and roar of the city, is fresh power brought into this world, but rather from the quiet hillsides basking in the sun, from fertile, cultivated valleys and from the broad solitudes of grazing lands, where our crops and our pastures in silence and without observation do this mighty work.

To increase the efficiency of crops in gathering this sun energy, and to store and supply it for the world, is FARMING. The farmer's work is the foundation, the necessary beginning of all human activity.

Let us notice some of the things involved in this work.

The idea that the farmer puts in his seed in the spring, kills some weeds during summer, takes an abundant harvest in the fall, and that the Lord does all the rest is a common and a pretty one, but rather crude. Farming, like every other business, is fighting.

There was a time, in the days of the early 
settlers, when the flint-lock musket was as necessary a farming tool as the plow-and it is admitted that farming then was a fight. But today the farmer must carry a knapsack sprayer if not a musket and he has to fight with the weather, with the soil, with fungi and with a multitude of insects more numerous than Indians, which are always likely to scalp,- - not his family, to be sure, -but his crops.

Crop production depends, of course, in the first place, on the conditions of weather, temperature and rainfall, and it is a common saying, true enough in a way. that we cannot help the weather. Of course, if it rains not at all, or rains every day, all our work is in vain. But such a state of things never occurs here. We sometimes have long periods of drought and again very wet seasons, when our crops suffer greatly, to be sure, but are not entirely cut off, and in such times as these we CAN help the weather; especially can we help a deficient rainfall. We cannot draw rain out of the sky, to be sure, but we can draw it out of the earth with the cultivator, which is the Eastern farmer's irrigating plant. That old book farmer, Jetho Tull, opened the way with his essays 
on horse cultivation, and the book farmer of today is alive to its importance. Let me give an illustration or two.

The summer of 1900 was exceptionally dry. Peaches set well, but there was not enough rainfall to carry out the crop, and in many orchards the fruit withered or was small and the foliage turned yellow. But not far from my home was a fifty acre orchard set on a hill, the foliage shining from afar, dark green up to harvest time, and a crop of five baskets to the tree of prime peaches; while others having the same soil and exposure failed. Why was it? The owner knew that very shallow and constant cultivation was as good as a mulch, and tremendously checked the drying out of the soil, leaving the water already in it for the use of his crop. Every day from late June till late August he had the cultivator going through his orchard, and after marketing his peaches for about $\$ 1.00$ a basket he knew that it paid.

"Cannot help the weather?" forsooth. But you can.

In February following that season he and his son both fell sick of pneumonia. But he did not make his will nor send for the minister. He told his doctor to get two 
of the best trained nurses he could find and call a city physician in consultation, "for," said he, "I've got to be alive with all the spring work coming on!" And he was.

Now an example of the other sort. I know poor book farmers of the unconscious sort, who believes cultivation in dry weather helps tobacco because it throws damp earth against the stalks; and they cultivate deep and half ruin their crops sometimes, not understanding that all the earth you stir dries out the more for the stirring and that, to keep land from drying out, the shallower you cultivate the better.

Let us pass on from the weather, about which Mr. Warner remarked that there was "a great deal said, and nothing done."

Most of the dry matter in our crops comes out of the air and not out of the soil, as many people are apt to think. It is safe to say that at least nine-tenths of the dry matter of all our farm crops comes in this way. But farm experience and laboratory experiment both show that the mineral matter supplied by the soil, though relatively small in quantity, is absolutely essential to the life of the crop. Chemistry has shown us what particular mineral matters are essential and what are of no use, and also which 
of the essential things are most commonly deficient in our farm lands. Our book farming and our farm experience have taught us that the use of manures and of commercial fertilizers is often necessary and profitable and that success always depends upon the skill with which they are used. The crop must always be fed by the farmer, but manures and fertilizers are not the only means of feeding it. Thorough tillage will often supply all that the crop needs of plant food, by unlocking it from its combinations in the soil, making it soluble and thus available to the crop. Not always and everywhere will commercial fertilizers pay. They should be the last resort of the book farmer. When his land is well drained and yet has sutficient water, when the stable manure has been all well handled and applied, and when the owner is ready to follow up all with thorough tillage, then, and not till then, will it pay him to consider commercial fertilizers to put just the last touch on the razor edge of the crop production.

The poor book farmer looks upon commercial fertilizers as a kind of patent medicine good to cure every fault of the land or the farming. It is pretty clear that the re- 
lations of chemistry as well as soil physics to farming are very close.

To properly feed the crop and to protect it, as far as can be done, from the vagaries of our climate, are but a small part of the work of farming. Every year farming becomes more and more a fight with fungi, bacteria and with insects, - a fight which would be perfectly hopeless without the constant aid which science gives, which the thrifty book farmer takes intelligently, and which finally, by round-about ways, reaches the comprehension of the unwilling and scoffing book farmer.

The Irish famine was largely the result of the potato rot, a fungous disease which is found wherever potatoes are grown, whenever the season favors its development. It is not very long ago that we knew neither what caused nor what cured it. Now we know both; thanks to the studies of botanists and to those who have made practical application of their work, and those who raise the most and best potatoes for market would no more omit the use of the preventive Bordeaux mixture than they would omit hoeing the crop.

Some years ago we found a man about to cut down his quince orchard because 
the trees were "blighted," as he expressed it, each year and bore no sound fruit. The trouble was a fungous disease very prevalent there, called leaf spot, which turned the foliage brown and prevented the growth of any healthy wood. This had infected the orchard ever since it was set out. He was willing we should treat it, so the alternate rows were well sprayed with Bordeaux mixture, leaving the others unsprayed for an object lesson. At the end of the first year the sprayed rows had made a fresh growth of wood and the foliage was almost perfect. There was little fruit, none of it good, because there was no second year wood to bear it. But we had banished the disease from the sprayed trees. The next year the treatment was repeated, and from his sprayed rows he sold $\$ 75.00$ worth of fruit at a special price because it was so large and fair. From the unsprayed rows he did not get a dozen sound quinces. But the best thing he got out of it was the knowledge that plants have their infectious diseases, as well as animals, that any infectious disease is a preventable disease, and that sanitation in the orchard and garden is just as necessary for the health of plants and the success of the farmer as 
sanitation in city and country is necessary for the public health.

But this result in the quince orchard would have been impossible, but for the laboratory studies of scientific men, who perhaps had no thought of any practical results, and for the studies of other men who were seeking chiefly a practical result. For the success of the work it was necessary to know the name of that particular fungus, how it grew and fruited and where it spent the winter and at what season it first attacked the leaves, things which no practical farmer has time or equipment to find out by his own observation. But any farmer in this room can, with very little trouble and with no expense, find out just what to do if his quinces are infected with the leaf spot, which, in most cases is all he wants, or he can learn all that is known regarding this pest. Isn't it worth his while to be a book farmer?

Not less destructive than the fungi are the hordes of insects which the farmer has to fight and which every year take millions of dollars from the income of farmers:the cotton boll weevil, the chinch bug, the locust, the codling moth, the San Jose scale and a host of others. Each has a dif- 
ferent habit, life history, time of occurrence and vulnerable point where it may be successfully attacked. All these things must be learned by specialists who devote their lives to such work: the entomologists. But the farmer must get at the results of their studies from books or from their readers in order to protect himself.

The canker worm formerly attacked almost yearly our elms in New Haven, which were the pride of our city, took off most of their leaves in June and threatened in time to kill them. Nothing was done but to talk and grumble at the bad taste of the English sparrows who would not eat them, till the entomologist pointed out that the female was wingless and that the newly hatched young did all the damage. Tarred bands about the tree trunks for a few months each year keeps the adult females from creeping up the trees and saves the foliage from all harm of this sort.

Just one illustration more. The dreaded San Jose scale is in our orchards and has been there unobserved for some time, multiplying and sapping the life of the trees. The eastern States are pretty generally infected. It is an insidious thing, being quite small and inconspicuous and often its pres- 
ence is only suspected when the trees become sickly. We are just in the midst of a fight with it. The best means of destroying it has not yet perhaps been devised but our most successful fruit growers, who have followed all that has in done in laboratories and orchards by way of experiment, have already learned enough to work intelligently and are keeping it in check and will, I believe, keep it off from their orchards and get well paid for their intelligence. Others are waiting to see "what luck" their competitors have with their book farming, and will lose many of their trees and most of their profit before they borrow a spraying outfit and get their coats off.

One more thing. Farming is business. There was a time when a distinction was made between the three "callings," viz., learned professions, business and farming; the last being looked upon as quite as different from business as it was from law or medicine. Whatever truth there may have been in this a century ago has gone out of it. Farming now must be managed as any other kind of business venture is managed. The farmer is a producer or, if you will, a manufacturer. He has something to sell 
which is a product of paid labor, and to sell in open competition with all other farmers. He has to buy labor and materials for his business. He has to find his market and he must watch it. I believe there are as good opportunities of financial success in farming as in most other kinds of legitimate business, but that the most common cause of partial or complete failure in it is, not lack of industry or skill in production, but lack of the business instinct in trading; in buying and selling.

Not long ago, in a farmer's institute in my own state, during a discussion on the construction of stables, there up-ended himself a quaint looking man with a solemn face but a very keen eye, and said, "Mr. Chairman, the last speaker talks about 'clear pine.' What kind of clear pine do we git when we call for it? Why, farmers' clear pine. I ordered some a while ago and it's out there on the track now. Runs abaout twelve knots to the foot and half on 'em is aout. We look around this state and what do we see ? We see farmers payin' more for raisin' the ir stuff than they git for it when it is raised, and they're tryin' to live on the difference."

That is a plain and truthful and pathetic 
picture of the curse of too many Connecticut farmers. I hope there are none of that kind hereabouts.

Let me give you an illustration of what I mean.

A man in the eastern part of my own state some years ago bought a thousand Japanese plum trees of $\mathrm{Mr}$. Hale, our great fruit man. He paid for them and Hale heard nothing more for a while, but one day he got a postal from this customer which read, "Mr. Hale, if you want to see plums come down here." Hale didn't want to see any plums except his own just then, which were keeping him busy, but having business in Providence, he stopped off for a few hours just to take a look at his friend's fruit. He found his house, but his wife said her husband was off down the road with the team. Could she tell him where the plum trees were? Oh yes, they were five minutes walk down the road on the left, so down there he went. The trees and land had been well cared for. The trees were full, too full, of ripe plums. They were dropping already and the ground was thick with the luscious fruit, ripe and rotting. Hale was made almost wild with the waste of it and the owner was "down 
the road." Soon he came in sight, jogging home with some crates in his cart, and joyfully greeted Hale with the remark, "Pretty thick, ain't they ?" "Man!" shouted Hale, "what are you doing with them." "Well," said he, "I'm peddlin' down the road." "Do you know you've got $\$ 500$ worth of stuff going to waste here, with your infernal 'peddlin' down the road? ', "Well," said the farmer, "they've got a little ahead of me, but what can I do?" "Do?" said Hale, "Jump. That's what. Is there a telephone within five miles?" There was, and under Hale's outpouring, the man jumped, the horse jumped, everything jumped. He sent a telegram to New York for crates and baskets to come up on the afternoon boat, he telephoned a Providence commission man to take care of the shipment to be sent him the next night, he made the man engage pickers to be there at daylight, and the owner of the orchard had to spend all he had taken in " pedlin' down the road " for telephone and telegraph, and his knees smote together at the outlay, but they saved the greater part of the crop. There are samples of two Connecticut fruit farmers. Mr. Hale is a business farmer. He knows all the fruit 
markets, all the commission men, all the freight agents, all his competitors, all the fruit prices, and all the tricks of all of them. Nothing in fruit or in trade about fruit escapes him. The other man is learning. I don't believe he will ever be caught as badly again.

Bear with one other tale by way of illustration. The year when the grippe first appeared in this country and was so fatal, a farmer told me he was pushing his strawberry fields all he could and was cleaning up all his old beds which he had planned to plow up, because strawberries would be a paying crop. I asked the reason, which he gave. It was because of the great mortality from grippe. One great business in the city where he marketed was the making of coffin trimmings. He said factories were running overtime, the men were making great wages, would have money to spend, and the first fresh fruit would surely catch their money - and it did! The story is rather gruesome, but that man had the business instinct. He was looking for a market and suiting his work to meet a foreseen demand.

What I have tried to show with homely illustration are these things: 
The problem of the farmer is a scientific problem: to secure energy from the sun for the use of the world as largely and as cheaply as he can and sell it as well as he can.

In his work he is constantly fighting unfavorable physical conditions; deficient or excessive rainfall, deficient sunlight and the exhaustion of his soil.

His crops are exposed to infectious and devastating diseases, - the work of fungi and bacteria,- and they are attacked by many kinds of insects which, unless checked, will work ruin.

These diseases and insect attacks can only be successfully fought when the nature and habits of the enemy are known, and this knowledge can only be obtained by a trained specialist. The farmer has ineither the time nor the equipment for such work.

Moreover, he meets other obstacles, fully as great as any of these, in business competition. It is not only the nature of his soil and climate which determines for him what crops he can or cannot profitably raise. The matter is often settled for him by railroad transportation rates, by the business outlook, even by public health. 
To succeed he must be not simply a tiller of the soil, but a keen man of business; quick to take advantage of the market, to foresee a time of scarcity, and to meet it in selling and avoid it in buying. He must have the business instinct.

Now the farmer cannot be a physician, a chemist, a botanist, an entomologist, and a student of market conditions, but he needs must have the help of them all. That help today is freely offered and readily accessible to him in print. Does it need any talk to demonstrate that he must be a reader or fail of entire success? I think not.

Then let us talk no more about it, but rather consider for a few minutes how he shall read and what he shall read. Books have been written on How to Read. I am helpless to do more than offer one or two hints specially regarding farm literature.

For one thing, the farmer must read as he would listen to the talk of a new acquaintance, with a wide-awake judgment of what he reads or hears. There is nothing inspired or infallible in a printed page. The writer is likely to be more guarded in his statements than the casual speaker, but he cannot tell the whole truth. He cannot avoid the chance of being unconsciously 
misleading in some of his statements. He may be too positive or he may be over-cautious. The reader must constantly weigh and judge and take what is written in the light of his own judgment.

For another thing, the book farmer should not read his farm books as the kitchen girl reads her cook book, expecting to find just the particular direction and receipt which will insure success. Farming cannot be reduced to any such simplicity. Farm books and farm reading are a help, an indispensible help, but they are not the farmer himself. They are tools, like his plow and cultivator and harvester, which cannot be taken directly from the warehouse to the field, but must always be adjusted, set, and prepared by the use of common sense to the special job on hand. What he reads will, in most cases, need to be fitted in, by his own common sense, to the special conditions of his own farm and his own market; just as a joiner builds and fits into his plan of a house the materials furnished him by the lumber dealer.

Just one other thing in passing. Learn to read as an amusement, a diversion, not as a religious duty. Do you smoke? So do I. It is a pernicious habit which ruins 
the health. But if you smoke, you can understand what I mean when I say, do your reading as you do your smoking-i. e., according to your mood, and at odd times, and have your reading as you have your pipe and tobacco, not neatly put up in the book-case, but always within reach of your easy chair. You can learn to do it. Here is a solid bulletin on the ripening of cheese, with a gnod many hard words in it, which requires attention and patience, but interests you. It is like that old briar wood of yours with a stem of rather small bore, which needs a strong pull and constant nursing to keep it lighted, but has a good flavor of its own and just suits your mood now and then. Here's another bulletin with really nothing in it which you didn't know before, but skim it through, just as you take that other pipe, a trifling affair, with a free draft and small bowl into which you put some mild tobacco when you only have time for a few puffs. Here is a bulletin full of scientific names and polysyllables and technical descriptions, closing by saying, "No remedy has been found for this plant disease, which bids fair to be very destructive." Do with 
that as you do with a Wheeling stogy, throw it in the fire half smoked. The butt of it is very bitter. Why spoil your digestion with it? Then there is other literature, rare as a choice Havana cigar, which you read as you smoke when you have a plenty of time to enjoy its incense, slowly, happily, only sorry that really delightful reading and really choice cigars are so scarce and hard to find.

Now this last suggestion is not for the young who are to form "habits of study" and take "courses of reading," but for those of us who are older and pressed by a multitude of cares and who must make our reading a pleasure and relaxation, if we do it at all.

As for the young, I repeat, smoking is a pernicious habit and only useful for purposes of illustration.

And last of all, what shall the book farmer read?

He ought certainly to see all the Bulletins and Reports of your two agricultural stations, the one at Geneva, the other at Cornell University in Ithaca, - both of them model institutions, - and he ought to read carefully in them all that bears on the farm topics in which he has an interest. These 
he can get, as they are issued, without charge, for the asking. Is he a dairyman? He will find in one bulletin analyses of all the feeding stuffs sold in this state and a discussion of their relative value, calling special attention to the inferior, worthless and adulterated brands. With an hour's attention he can learn which supply protein in the cheapest form, and that is what he needs to buy, and which supply chiefly starch and woody fiber, which he can raise at home cheaper than he can buy.

Is he thinking of buying commercial fertilizers? He has at hand analyses of all the brands sold in New York, and can see just what is available for him and can compare prices and quality.

In other bulletins he will find what has been done to prevent potato blight, the San Jose scale, fungous diseases of the grape, the raspberry, the black rot of cabbage and what is known as the pink rot of apples, discussions regarding the protection of shade trees, bean growing in this state, the cost and profits of poultry raising, and a great deal of interest and importance about cheese making. Bulletins on all these subjects have appeared from your stations 
within the last year. You need this information. It is spot knowledge.

There is the weekly agricultural paper which one cannot do without, for market reports and other information. Then one must have a paper relating to his particular branch of farming, dairying, bee-keeping, poultry raising or whatever it may be.

The book farmer also wants to know BY TITLE all that is published by the U, S. Department of Agriculture, although much of it he will not care to read. And this is the way to do it. Write to the Division of Publications, of the U. S. Department of Agriculture at Washington, D. C., and ask to have sent you (or your grange) the Monthly List of Publications. This shows you at once what has been issued, where to get it and, if a charge is made for it, what that is. When a title promises well, send for the article.

In these ways the book farmer can keep himself well informed on all that is newly issued relating to the problems of his particular farm. Ought he to do any less than this, if he is making farming a real business?

And all this is perfectly possible for any one, even the very busy man, who gets 
the habit of catching up and reading something worth while in his spare minutes. This is but a small part of what he might read with profit, but I have exceeded the time I set for myself and I cannot catalogue any further.

This farm sermon should close with a personal exhortation. For the comfort of our families, for the good of our own souls, for the joy of our own lives, let us be by all means book farmers, but not readers of farm books only.

When one leads a busy life in a somewhat isolated place there is danger that one will get out of touch with the world and with what is engaging its best thought. So one may lose company with others, become narrow and have no great thought to refresh himself withal when the pettiness of his own life and work comes over him. The best weapon of defense against all this is good reading.

There is rest for body and soul in Lowell's Essays, Lanier's poems, Fiske's historical writings, Thackeray's novels and Kipling's Jungle Books. They, or books like them. should be in every house. Each season should mark some addition to their number and considerable wear on the older 26 
bindings. To hurry through books for the sake of "doing some reading" or keeping up with some reading circle is sinful. To read a good book, which one likes, half a dozen times through is righteous.

Let us book farmers know something of books of travel, of history, of fiction, of poetry. Let us have, in the isolation of our farms, something of the sweet companionship of good literature ; a companionship which knows no separation and is very safe from change. 

5030.1908 



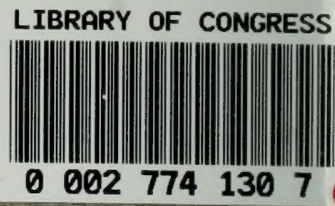

